

IZADP No. 2384

Wage Determination in the U.S. Airline Industry: Union Power under Product Market Constraints

Barry T. Hirsch

October 2006 


\title{
Wage Determination in the U.S. Airline Industry: Union Power under Product Market Constraints
}

\author{
Barry T. Hirsch \\ Trinity University \\ and IZA Bonn
}

Discussion Paper No. 2384

October 2006

\author{
IZA \\ P.O. Box 7240 \\ 53072 Bonn \\ Germany \\ Phone: +49-228-3894-0 \\ Fax: +49-228-3894-180 \\ E-mail: iza@iza.org
}

Any opinions expressed here are those of the author(s) and not those of the institute. Research disseminated by IZA may include views on policy, but the institute itself takes no institutional policy positions.

The Institute for the Study of Labor (IZA) in Bonn is a local and virtual international research center and a place of communication between science, politics and business. IZA is an independent nonprofit company supported by Deutsche Post World Net. The center is associated with the University of Bonn and offers a stimulating research environment through its research networks, research support, and visitors and doctoral programs. IZA engages in (i) original and internationally competitive research in all fields of labor economics, (ii) development of policy concepts, and (iii) dissemination of research results and concepts to the interested public.

IZA Discussion Papers often represent preliminary work and are circulated to encourage discussion. Citation of such a paper should account for its provisional character. A revised version may be available directly from the author. 


\section{ABSTRACT}

\section{Wage Determination in the U.S. Airline Industry: Union Power under Product Market Constraints*}

The paper analyzes wages in the U.S. airline industry, focusing on the role of collective bargaining in a changing product market environment. Airline unions have considerable strike threat power, but are constrained by the financial health of carriers. Since airline deregulation, compensation has waxed and waned in response to the industry's economic environment. Airline workers capture sizable rents following good times and provide concessions following lean times. Compensation at legacy carriers has been restructured; it remains to be seen if compensation will continue its long-run movement toward opportunity costs. Evidence from the CPS for 1995-2006 shows that wage premiums for airline industry workers remain, particularly for pilots, with existing premiums almost entirely a union phenomenon. Much of the gap in wage scales between major and mid-size carriers was erased in the mid-2000s concessionary cycle, but these rates remain much higher than rates at regional carriers. Compensation levels at regional carriers may approximate opportunity cost - the compensation necessary to attract and retain qualified employees throughout the industry. Because unions retain bargaining power at the major carriers, wages are likely to head upward as carriers' financial health returns. Such wage levels may or may not be sustainable in the inevitable next downturn.

JEL Classification: J30, L93, J50

Keywords: airlines, wages, bargaining, unions, comparability, wage cycles, bankruptcy, CPS

Corresponding author:

Barry T. Hirsch

Department of Economics

Trinity University

San Antonio, TX 78212-7200

USA

E-mail: bhirsch@trinity.edu

\footnotetext{
Prepared for the volume, Advances in Airline Economics, Volume II: The Economics of Airline Institutions, Operations and Marketing (editor, Darin Lee, forthcoming, 2007). Helpful comments were received from Gary Fournier, Jim Gillula, Darin Lee, and seminar participants at the University of Kentucky. I thank Dan Kasper and Darin Lee for providing Form 41 labor cost data. Figures cited in Section 5 reflect work done with Michael Wachter and James Gillula, presented in United Airlines' 1113(c) bankruptcy hearing. The views expressed in this paper are mine and need not reflect the opinion of others.
} 


\section{Introduction}

The air transportation industry has realized rapid growth throughout its history. Despite this growth, carrier profitability since deregulation has proven volatile and corporate viability far from certain. With one exception, every major carrier at the time of deregulation in 1978 has either failed, had its operations merged into another airline, or been in bankruptcy protection. The exception, American Airlines, narrowly avoided bankruptcy in 2003 following wage concessions from its unions.

As is the case for most companies, labor compensation among airlines accounts for a substantial share of total costs. ${ }^{1}$ In much of the industry, compensation is determined through collective bargaining; thus, workers' pay may deviate substantially from opportunity costs. While union density economy-wide has sharply declined, the airline industry has remained highly unionized. The percentage of workers who are union members in the air transportation industry was $49.2 \%$ over the $1973-78$ regulatory period and 49.4\% in 2005. Union coverage rates for flight personnel and ground workers are higher. In contrast, private sector union density economy-wide fell from $24.2 \%$ in 1973 to $7.8 \%$ in $2005 .^{2}$ No private sector industry has union density as high as does air transportation. ${ }^{3}$

More than in any other private industry, airlines face unions who possess substantial bargaining power, that power emanating from the ability of a strike to shut down and bankrupt a carrier. Of course, it is not in the interests of workers and their unions to destroy their employers, so union demands are constrained by the financial health of carriers. Hence, the airline industry has developed a compensation pattern in which its union workers "tax" potential profits following the onset of good times, but agree to moderate contractual pay increases or provide wage and benefit concessions following the onset of bad

\footnotetext{
${ }^{1}$ During much of the 1980s and 1990s, labor costs accounted for about a third of total expenses. This share peaked at 38\% in 2002, a level not seen since 1979 and in the earlier regulatory period. The labor cost percentage fell substantially after 2002, to $36 \%$ in 2003, 30\% in 2004, and 26\% in 2005 (24\% in 2005:4). Fuel costs, which accounted for $12 \%$ of total expenses in 2002, rose to 23\% of expenses in 2005 (Air Transport Association, 2006, Labor and Fuel tabs).

${ }^{2}$ Union density figures are compiled from the Current Population Survey (CPS). The 1973-78 air transportation figure is in Hirsch and Macpherson (2000, p. 136), while the 2005 figures for air transportation and the private sector are from Hirsch and Macpherson (2003, updated annually at www.unionstats.com). Prior to 2003, the air transportation industry included air courier services (e.g., largely nonunion FedEx), which were small during 197378. Were these included in the 2005 figure, union density would be about 10 percentage points lower.

${ }^{3}$ Two industries have higher union density, the predominantly public railroad transportation industry and the entirely public U.S. Postal Service (www.unionstats.com).
} 
times. For many if not most airlines and their unions, this product market union wage cycle has been accompanied by a contentious labor relations environment with no small amount of distrust on all sides. ${ }^{4}$ 5

Following the strong financial health of the industry in the late 1990s, generous labor contracts and high labor costs took force in the early 2000s. The increased compensation was accompanied by a “perfect storm” of negative events - a recession in 2001, sharp declines in traffic following the September 11, 2001 attacks, Internet pricing, increasing market shares among “low-cost carriers” and concomitant declines among hub-based legacy carriers, and, more recently, high fuel costs over a sustained period (which began to moderate in the latter half of 2006). The convergence of high operating costs and intense price competition resulted in bankruptcies among four legacy carriers (US Airways, United, Delta, and Northwest) and several mid-size and regional carriers. During 2004-2006, wages and benefits among the legacy carriers have been falling, either under the threat of or following bankruptcy. ${ }^{6}$

The recent restructuring of labor costs in an increasingly competitive airline industry has been substantial. Lower labor costs, a decrease in debt burden among carriers emerging from bankruptcy, relatively strong demand, and reduced capacity among the legacy carriers have improved major carriers' financial prospects. At the same time, high fuel costs and, more fundamentally, the emergence of more competitive product markets and a high level of price competition, have served to keep profits at low levels, at least through mid-year 2006. But the future will not be an extension of the present. During the two decades following airline deregulation, periods of union wage concessions have been followed by rebounding wages as airlines’ profits recovered. Continuation of this pattern requires not only the

\footnotetext{
${ }^{4}$ There is a large industrial organization literature on the airline industry, but little on the airline labor market. References to past studies are provided in Hirsch and Macpherson (2000); see, for example, Card (1998), Crémieux (1996), and Johnson (1995). Nay (1991) provides an early statement on union wage cycles in the airline industry. ${ }^{5}$ Airlines differ from other U.S. private sector industries in that collective bargaining is governed not by the National Labor Relations Act (NLRA), but by the Railway Labor Act (RLA) of 1926, amended in 1936 to apply to the airline as well as railroad industry. As compared to the NLRA, the RLA provides more specificity as to the negotiation and mediation procedures that parties must adopt in a labor dispute prior to a strike. The bargaining structure that evolved under the RLA was decentralized, with separate unions by craft and carrier-specific contracts. ${ }^{6}$ Companies in bankruptcy cannot unilaterally void their union contracts and implement lower pay but, under U.S.C. $\S 1113(\mathrm{c})$, can request that a bankruptcy judge do so. The company must show that wage and benefit cuts are necessary for the company to successfully emerge from bankruptcy and that the cuts are equitable. The equity provision can be examined through a comparison of contract rates with estimates of market compensation and by showing how pay cuts are distributed across employee groups. In most cases, the employer and union agree on new wage and benefit terms, often with prodding from the judge, prior to a decision being made on voiding a contract.
} 
presence of strong unions that can appropriate company profits, but also product market innovations and a degree of pricing power that generate profits to be taxed. ${ }^{7}$

The purpose of this paper is to examine the role of unions and describe recent wage determination in the airline industry. A key question posed in this study is whether or not the current decrease in wages and benefits in the industry represents a permanent shift in the level of compensation, or whether there will be a resumption of the historical cycle of rising union wage premiums following the onset of good times and subsequent wage concessions following lean times. In order to address this question, it is critical to estimate the level of opportunity cost wages in the airline industry. Subject to a number of caveats, well know in the labor economics literature, compensation in competitive markets will tend toward opportunity wages - what similar workers in similar jobs might have obtained in alternative employment. ${ }^{8}$ Compensation cannot be expected to fall below a competitive level, at least not for any sustained period. Thus, a reasoned judgment as to the pattern of future wages in the airline industry requires that we know how airline wages diverge from opportunity wages. To estimate this divergence, it is necessary not only to compare the wages of unionized airline employees at legacy carriers to wages elsewhere in the airline industry, but also to the opportunity wages outside the industry.

The plan of the paper is as follows. Section 2 provides a brief discussion of how the level and dispersion in airline labor costs have changed over time. Section 3 provides analysis on overall airline industry wage differentials using the Current Population Survey (CPS) for 1995 through 2006, focusing on the unionized sector of the air transportation industry. Section 4 follows with a more detailed focus on union and nonunion CPS wage differentials by airline industry “craft” (pilots, flight attendants,

\footnotetext{
${ }^{7}$ Although not addressed in this paper, union wage demands may be constrained by a company's level of debt, given that increasing leverage reduces liquidity. Knowing this, union companies' optimal debt levels will be higher than for nonunion companies. For theory, supporting evidence, and references to prior literature, see Matsa (2006).

${ }^{8} \mathrm{~A}$ wage premium is defined here as payments to labor beyond long-run opportunity costs; that is, what workers could have earned in an alternative job path entailing similar investments in training and similar working conditions. Employees' current pay is often greater than the pay they could get at an alternative job. These short-run premiums (quasi-rents) derive from costs associated with job mobility, firm- and industry-specific skills, and implicit contracts in which earnings deviate from spot marginal products. Efficiency wage theory proposes that in some settings, wages in excess of opportunity cost may lower per unit costs and are thus consistent with profit maximization. The reasoning is that in workplaces with high monitoring costs, voluntary effort may increase in response to high wages, either to reduce the risk of firing or as a result of positive reciprocity (these explanations seem to apply less readily to union than nonunion workplaces). For discussion, see Cahuc and Zylberberg (2004, pp. 353-60).
} 
mechanics, fleet service, agents, and other). In section 5, carrier contract data are presented that permit a comparison of pay by craft at major carriers with pay for those same occupations at regional airlines. A final section of the paper addresses, but does not fully answer, the two questions stated above. First, given the evidence, what is the level of opportunity cost wages? Second, will the future be one in which earnings move toward opportunity costs or will we continue to observe cycles in which union wages rise well above and subsequently fall toward opportunity costs, depending largely on airlines' ability to pay?

\section{Airline Labor Costs Over Time}

Labor cost is only one of many determinants of an airline’s financial health, but it is an important one. In each of the three years from 2001-2003, the four airlines with the highest compensation per employee (Form 41 salaries and benefits, as presented below) were US Airways, United, Northwest, and Delta. Dispersion in compensation across airlines was relatively high. Not coincidentally, these four airlines ended up in bankruptcy protection. ${ }^{9}$ American, a close fifth in labor cost per employee during 2001-2003, went to the brink of a bankruptcy filing in 2003, backing off from filing following concessions from its unions. Wage and benefit concessions at high-cost carriers have led to declines since 2003 in average industry compensation per employee and in pay dispersion across airlines.

Much of the analysis in the paper utilizes the CPS, the monthly household survey of individuals conducted jointly by the U.S. Bureau of the Census and Bureau of Labor Statistics. The CPS, however, is not ideally suited to track year-to-year changes in airline labor costs among large national carriers. First, sample sizes of air transport workers each year are not large. Second, a portion of air transport workers do not work for passenger airlines and, among those working for airlines, one cannot differentiate employees of major versus regional or other airline services. And third, the CPS allows one to measure earnings, but not the dollar cost of benefits.

Form 41 data reported by certificated carriers to the Department of Transportation (DOT) is better suited than CPS data to track airline labor costs over time. Figure 1 presents average total compensation (real salaries and benefits, in 2005 dollars) per airline employee during 1990-2005, and the dispersion

\footnotetext{
${ }^{9}$ US Airways entered bankruptcy protection in 2002 and again in 2004, United in late 2002, and Delta and Northwest on the same day in September 2005.
} 
across airlines in average compensation. ${ }^{10}$ The data include all major and most national carriers. ${ }^{11}$ The number of carriers differs by year, as smaller airlines move in and out of the industry or mergers occur; there was a maximum of 19 in 2000 (with 12 in 1990 and 13 in 2005). ${ }^{12}$ Calculations are based on weighted averages, with airline employment by year as weights. Compensation and, subsequently, costs per available seat mile (ASM) are expressed in 2005 dollars using the CPI-U (current series).

As evident in Figure 1, average real compensation among carriers (shown by the “diamonds”) increased briskly through 1994, stayed relatively flat (or fell slightly) throughout the rest of the 1990s, and then increased after 1999. One sees large increases in average real compensation in 2000, 2001, and 2002, followed by small, moderate, and large decreases in 2003, 2004, and 2005, respectively. The real level of compensation in 2005 is similar to that seen in the mid-1990s.

\section{[INSERT FIG. 1 HERE, Caption: Airline Wages and Benefits, Level and Dispersion, 1990-2005]}

Also shown in Figure 1 (see the "squares") is the dispersion in compensation across carriers, measured by the employment weighted coefficient of variation. High pay dispersion generally produces cost differences that cannot be sustained. Dispersion decreases when low-pay airlines play catch-up and/or when high-pay airlines fall back toward the pack. Pay dispersion had declined during the late 1990s, but increased following pay hikes taking effect in 2001-2003. Wage and benefit concessions since 2004 among the high-cost carriers have reduced pay dispersion.

Figure 2 provides an alternative measure of labor costs constructed from Form 41 data, measuring cents per available seat mile (ASM), in 2005 dollars, for 1990-2005. Obviously, labor costs per seat mile are affected not only by costs per worker, but also by employment, productivity, airline capacity, and the like. The pattern evident in Figure 2 (see the “diamonds”) is one of a gradual but steady decline in real

\footnotetext{
${ }^{10}$ The values shown in Figures 1 and 2 are provided in Appendix, Table 1. Daniel Kasper and Darin Lee of LECG kindly made available Form 41 information on compensation and labor costs per ASM by airline. Employment data for certificated carriers, used to construct weights, were obtained from the Bureau of Transportation Statistics at http://www.bts.gov/programs/airline_information/number_of_employees/certificated_carriers/index.html.

${ }^{11}$ The DOT defines a national airline as having at least $\$ 100$ million in annual revenue and a major airline $\$ 1$ billion.

${ }^{12}$ In 2000, included airlines accounted for 91\% of total employment among all DOT 41 "major" and "national" certificated carriers (excluding Airborne Express, FedEx, and UPS). In 1990 and 2005, the corresponding numbers were $87 \%$ and $81 \%$, respectively. The "low" figure in 2005 reflects sharp declines in employment at the included large legacy carriers included in Figure 1, coupled with growth in employment among small airlines not included.
} 
labor costs per ASM from 1990 through 1997, modest increases in costs until 2000, an upward break with sharply increased costs in 2001 and 2002, followed by substantial decreases after 2002, from 4.7 cents per ASM in 2002 to 3.3 cents in 2005. The recent decline in costs per seat mile came about not only through decreases in compensation per worker, but by steep declines in employment at the legacy carriers.

\section{[INSERT FIG. 2 HERE, Caption: Labor Costs and CV Per Available Seat Mile, 1990-2005]}

Figure 2 also shows the dispersion across carriers in labor costs per ASM. The coefficient of variation (the "squares”) stayed constant at about 20 through the 1990s, but declined sharply in 20032005 to about 15 . Undue weight should not be placed on this single statistic, but by this measure the cost structure across airlines was more similar in 2005 than at any time since at least 1990. All else the same, similar cost structures across airlines should be associated with more stable prices and financial outcomes.

\section{Wage Differentials in the Air Transportation Industry: Measurement and Data}

Are unionized airline workers paid wages above (long-run) opportunity cost? If so, how large are these premiums? Do wage premiums vary across airline crafts? And do nonunion as well as union airline workers receive premiums? These seemingly straightforward questions are not easy to answer, at least not in a precise manner. The difficulty arises from a combination of methodological issues (e.g., what are the appropriate comparison groups for airline workers) and data limitations (e.g., company level data do not provide measures of worker attributes, while public data on individuals and their attributes do not permit one to easily examine differentials within the industry - say across major versus regional carriers or among those at passenger airlines versus air freight companies). Of course, limitations arise to some greater or lesser degree in all research endeavors. For the research questions posed in this paper, a variety of evidence allows one to paint a reasonably clear picture of wage determination in the airline industry.

This section follows and extends the approach utilized by Hirsch and Macpherson (2000) in their study of wage determination in the airline industry from 1973 through 1997 . The CPS analysis uses individual wage and salary worker data for September 1995 through May 2006. ${ }^{13}$ Following Hirsch and

\footnotetext{
${ }^{13}$ September 1995 is the first month following 1994 CPS revisions in which imputed earners, excluded from the analysis (see below) can be identified. May 2006 was the latest CPS file released when this paper's empirical analysis was executed. This ten-plus year period includes both low and high points in airline wage-profit cycles.
} 
Macpherson, six air transportation groups of workers are identified using the CPS - five airline crafts plus a residual category. The five craft groups are pilots, flight attendants, mechanics, fleet service (ramp and utility) workers, reservation agents and clerks, and an "other” category. For the five airline craft groups, comparison groups of individuals comprising workers employed in specific sets of occupations are identified. Workers in those occupations serve as comparison (control) groups in order to measure relative wages. For the "Other” category of airline workers, a comparison group of workers across the economy is used. Relative wage differentials between the air transport and comparison group workers are estimated within a regression framework, controlling for measurable worker, location, and job characteristics. Section 4 and Appendix Table 2 describe the construction of the CPS comparison groups for each of the six air transport groups.

The empirical approach is as follows. Separate wage equations by craft are estimated, with each regression sample from the 1995-2006 CPS including both an airline "treatment” group (pilots, etc.) and a large comparison group of workers. From each wage equation, whose coefficients are determined largely by the non-airline comparison group, I calculate log wage differentials for union and nonunion air industry workers, relative to measurably similar comparison group workers outside the air transport industry. Industry-wide wage differentials based on the full sample of air transport workers are calculated based on the weighted average across the six groups, using fixed air transport employment weights over the time period. In addition to controlling for a typical set of worker human capital, demographic, and location characteristics reported in the CPS (e.g., schooling, age, region), an occupational skill level and working condition variable, constructed by the BLS, is matched to the CPS. The principal purpose of this additional control variable is to account for occupational skill differences not fully captured by worker schooling and experience measures.

Specifically, let

$$
\ln Y_{i g t}=\Sigma \beta_{k g t} X_{i k g t}+\Sigma \Gamma_{g} U \cdot A i r_{i g t}+\Sigma \theta_{g} N \cdot A i r_{i g t}+\Sigma \Omega_{c} O c c_{c i t}+\varphi \operatorname{lnSkill}{ }_{i}+\varepsilon_{i t}
$$

where $\ln Y$ is the natural logarithm of the wage, $i$ designates individual, $g$ indexes six airline craft groups and their corresponding control groups, and $t$ is year. Included in $X$ are $k$ worker and labor market control 
variables (listed below) with $\beta_{k}$ the corresponding coefficients. A “level of work” variable, Skill, defined at the detailed occupation level is shown separately since results are presented with and without its inclusion. Air is a dummy variable set to 1 for each of the $g$ air industry craft groups. Air is interacted with index variables designating whether a worker is covered $(U)$ or not covered $(N)$ by a collective bargaining agreement. Occ is a set of $c$ broad occupation dummies used only in the regression for “Other” air industry workers - the non-specified craft group and an economy-wide control group. Year dummies for 1997 through 2006 (Jan-May) are included in X, with 1995-96 the omitted base period.

Coefficients $\Gamma_{g}$ and $\theta_{g}$ provide estimates of log wage differentials by airline craft group $g$ for union and nonunion workers, respectively, in both cases as compared to the appropriate comparison group made up as a mix of union and nonunion workers. ${ }^{14}$ Weighted averages of these coefficients thus provide estimates of the airline wage differentials $d$ of interest. That is:

(2) $\quad d_{u}=\Sigma w_{u g} \Gamma_{g}$

(3) $\quad d_{n}=\Sigma w_{n g} \theta_{g}$

Estimates of the air transport log wage differentials are shown for union air transport workers $\left(d_{u}\right)$, nonunion air transport workers $\left(d_{n}\right)$, and union and nonunion combined. The differentials are estimated with and without control for lnSkill. The weights $w_{g}$ for union and nonunion workers represent the CPS employment shares of the six air industry worker groups fixed over the 1995-2006 period. ${ }^{15}$ CPS wage differentials were also estimated by year, but are not presented. Little systematic pattern is found, presumably due to large year-to-year variation in the air transport industry samples reporting earnings.

The air transport and comparison group samples include full-time non-student wage and salary workers ages 18 and over. To enhance the relevance of the comparison group, excluded are workers with less than a high school degree (with the GED categorized as high school) and education beyond a masters

\footnotetext{
${ }^{14}$ That is, union status is not included as a control in $X$. The assumption here is that the opportunity cost wage for each group is best approximated by an implicitly weighted average of union and nonunion wages.

${ }^{15}$ The weights are calculated prior to omission of imputed earners and using CPS employment weights. Use of fixed weights over time means that changes in the wage gap estimates result from wage changes and not from worker mix changes. Since imputation rates can differ across airline craft groups, weights are determined prior to the exclusion of earnings nonrespondents.
} 
degree. No education restrictions are placed on the air transport sample. In the regression analysis, the relatively few airline workers with less than a high school degree are assigned to the high school category and those few with a degree beyond the masters level are assigned to the masters category.

With the exception of flight personnel (pilots and flight attendants), full-time status is defined as reporting 35 or more usual hours per week on the principal job. The reporting of hours worked by flight personnel presents a problem, however, since some report only paid flight hours, while others report all hours away from home. Flight personnel who report 15 or more hours worked per week are retained as full-time workers. Usual weekly earnings reported by pilots and flight attendants is only weakly related to their reported weekly hours worked, ruling out the calculation of an hourly wage based on weekly earnings divided by weekly hours (construction of the wage is described below).

Approximately 25\%-30\% of workers in the CPS are either unwilling or unable to report their earnings. These individuals have weekly earnings “allocated” by the Census based on an imputation procedure in which nonrespondents are assigned the earnings of a "donor” with an identical set of match characteristics (Hirsch and Schumacher 2004). All those with imputed earnings are excluded from the analysis. It is important that they be excluded in order to avoid severe attenuation toward zero in wage gap estimates with respect to the airline industry and union status. Neither industry nor union status is a match criterion used to assign a donor's earnings to a nonrespondent. Hence, air transport industry nonresponents will typically be assigned the earnings of non-airline donors. Union nonrespondents will typically be assigned the earnings of nonunion donors. Broad rather than detailed occupation is an imputation match criterion, thus nonresponding pilots (aircraft mechanics, etc.) will typically not be assigned the donor earnings of other pilots (aircraft mechanics, etc.). Absent the exclusion of imputed earners (or use of a bias correction method), wage differentials with respect to industry, union status, and other non-match criteria will be seriously attenuated. Hirsch and Schumacher (2004) show that "match bias” (i.e., the attenuation in coefficient estimates) roughly equals the proportion of nonrespondents. ${ }^{16}$

\footnotetext{
${ }^{16}$ Match categories include education, age, gender, race, hours worked, broad occupation, and receipt of tips, commission, or overtime. Bias due to imperfect matching (e.g., a Ph.D. matched to an earnings donor from the B.A. or above category) is analyzed in Bollinger and Hirsch (2006).
} 
Imputed earners can not be identified in the CPS between January 1994 and August 1995. Hence the analysis in this paper begins with the September 1995.

Public use files of the CPS include an edited usual weekly earnings measure that is top-coded (i.e. capped). For years prior to 1998 (and after 1989), weekly earnings are capped at \$1,923 (\$100,000 annually) and for years since 1998 at \$2,885 (\$150,000 annually). Apart from pilots and a few managerial or professional workers, few air transport industry workers have top-coded earnings. For nonpilot air transportation workers and all comparison group workers with weekly earnings at the cap, they are assigned the estimated mean earnings above the cap based on year and gender-specific estimates that assume a Pareto distribution for earnings beyond the median (see Hirsch and Macpherson 2006, p. 6; posted at www.unionstats.com). Values are moderately higher than 1.5 times the cap, with somewhat smaller female than male means and growth over time.

Top-coded earnings among pilots is widespread, more so than for any other occupation in the CPS, but the right tail of their earnings distribution is probably less skewed than implied by the Pareto distribution (i.e., fewer extremely high earnings). During September 1995-Aug 1996, the first 12 months used in our sample, $20.0 \%$ of pilots who reported earnings were above the $\$ 1,923$ weekly earnings cap, as compared to $9.6 \%$ in 2000 and 14.3\% in 2005 with the higher \$2,885 cap that began in 1998 (Hirsch and Macpherson 2006). ${ }^{17}$ Because many senior pilot contracts are for amounts not far above the cap, I assign pilot means above the cap that are much lower than the Pareto means. For the years prior to 1998, pilots with weekly earnings greater than $\$ 1,923$ have their earnings set at 1.25 times the cap, or $\$ 2,404$. For years beginning in 1998, pilots with weekly earnings greater than \$2,885 have their earnings set at 1.25 times the cap, or $\$ 3,606$. These estimates seem likely to be conservative (i.e., produce too low a pilot/non-pilot wage differential). Moreover, use of the same multiple for all years fails to capture some of the highest pilot contract increases and subsequent concessions realized over this period. ${ }^{18}$

For air transport workers apart from pilots and flight attendants, plus all comparison group

\footnotetext{
17 The pilot sample in 2005 has an unrepresentative number of high earners as compared to earlier years and 2006.

${ }^{18}$ Regression estimates of pilot earnings premiums are about .10 log points higher when Pareto means rather than the more conservative 1.25 multiples are used.
} 
workers, the wage is defined as follows. Hourly earnings are calculated as equal to usual weekly earnings (which includes typical overtime, tips, and commissions) divided by usual hours worked per week. ${ }^{19}$ For pilots and flight attendants, reported hours worked per week are ignored, since variability across workers contains little information. ${ }^{20}$ For pilots, the wage is calculated as weekly earnings divided by 40 , while for flight attendants’ weekly earnings are divided by 36. This approach is explained below. Finally, the earnings measure for all workers is converted to 2005 dollars using the CPI-U (Current Series).

One cannot avoid making some rather arbitrary assumption as to how job-related hours among flight personnel compare to work hours among other workers. The earnings measure that is used implicitly assumes that job-related time spent by pilots (flight hours, wait time, and travel time) entails similar disutility on average as does 40 hours of paid work plus non-paid travel time for non-flight air transport and comparison group workers. For flight attendants, the assumption is that a typical week is equivalent to 36 hours of work in comparison group jobs. Pilots' mean reported hours worked in the CPS is 40.9 overall (and 39.7 for union pilots). Flight attendants' mean reported hours worked in the CPS is 32.5 overall (and 32.0 for those unionized). If the hours assumptions of 40 and 36 for pilots and flight attendants, respectively, overstate (understate) the disutility associated with hours worked by flight personnel, then the wage differential estimates for these groups are too low (high).

Included in $X$ - the control variables - are education dummies (5) reflecting levels from a minimum of a high school degree (including a GED) through a masters degree, potential experience in quartic form separately and interacted with gender (experience being proxied by the minimum of age minus years schooling minus 6 or years since age 16), gender, race/ethnicity (4), foreign born, region (8), metropolitan area size (6, with non-metro the base), year dummies (10), and broad occupation dummies (11, included only for the “Other” group regression).

\footnotetext{
${ }^{19}$ A small number of individuals do not report usual hours worked per week and instead have their hours worked value imputed (i.e., assigned) by the Census. These individuals are excluded from the estimation sample. For nonflight personnel and all comparison group workers, individuals who report "variable" weekly hours have the wage determined by usual weekly earnings divided by hours worked last week, which adds noise to the independent variable but is unlikely to bias coefficients.

${ }^{20}$ Commercial airlines hire few part-time pilots or flight attendants. Recall that those reporting less than 15 hours worked per week are excluded from the sample.
} 
In addition to the control variables in $X$, earnings differentials are estimated with an included occupation or job duties variable, lnSkill, compiled by the BLS for the approximately 500 Census occupation groups. As described in Pierce (1999), the unit of analysis for the National Compensation Survey is the detailed occupation cross-classified by work level. The NCS uses the Census occupation codes included in the CPS. For each Census occupation, 10 job attribute factors are defined, each with various levels. These are as follows: knowledge (9 levels), supervisory controls (5), guidelines (5), complexity (6), scope and effect (6), personal contacts (4), purpose of contacts (4), physical demands (3), work environment (3), and supervisory duties (5). Each of these job attribute factors and levels were awarded “quality points” by BLS analysts in order to develop a single occupational job attribute index. This occupational job factor index is highly correlated with earnings (Pierce 1999). Allegretto, Corcoran, and Mishel (2004) have previously merged this BLS index with the CPS and used it in their study of public school teacher salaries.

The job factor index, referred to here as Skill (but which measures a broad range of attributes, as indicated above), was obtained from the BLS for 1990 Census occupation codes (COC), used in the CPS through 2002. Beginning in 2003, the CPS adopted 2000 Census occupation codes, many of which cannot be mapped one-to-one with the 1990 COC. Codes used for the five airline crafts could be mapped cleanly. For the remaining air transport industry workers and all comparison group workers beginning in 2003, each worker was assigned a 1990 COC based either on a direct match to their current COC or from a probabilistic mapping between 1990 and 2000 COC provided by the Census. Skill was then matched to each worker's assigned 1990 COC. Included in the earnings equations is $\ln ($ Skill). Its coefficient $\varphi$ represents an elasticity; e.g., $\varphi=.25$ implies that earnings increase 2.5 percent for each 10 percent increase in the skill index. The BLS skill index does not cover Census occupations that are exclusively federal (e.g., Postal Service workers), private household, and agriculture, forestry, and fishing occupations. The exclusion of these occupations from the analysis reduced sample sizes very little. Earnings equation results (not including Skill) with and without these occupations are nearly identical.

\section{Earnings in Air Transportation and Among Comparison Groups: Descriptive Evidence}


This brief section provides descriptive evidence from the CPS on earnings differentials between union and nonunion air transportation workers and "comparable” workers outside the airline industry. A subsequent section examines the earnings premium estimates derived from the regression analysis.

Table 1 provides the CPS sample sizes, employment weights, mean earnings (in 2005\$), and BLS Skill index values for the air transportation industry, for each airline craft group (separately by union status), and for the corresponding comparison groups. As noted previously, the earnings sample for September 1995 through May 2006 includes only those who respond to the earnings question and not those whose earnings have been imputed (assigned) by the Census. The CPS sample size of air transportation industry workers over the period 1995-2006 is 6,835, with roughly equal numbers of pilots, flight attendants, and mechanics (about 900 each). The sample size of agents (reservation agents, gate agents, and stores employees) is moderately larger (about 1,200), while the sample size of the fleet service workers (i.e., baggage handlers, cleaners, and other ground workers) is substantially smaller. The residual group of “Other” air transport workers is quite large, about 2,600. Estimates of industry wage differentials are based on the weighted average of estimates across the six employee groups (jointly and separately by union status). The group weights (shown in rows labeled "Weights”) are calculated from the CPS sample, including those who do not report earnings, using the employment weights that the Census attaches to each surveyed worker.

[INSERT TABLE 1 HERE, Caption: CPS Mean Wages by Airline Craft and Comparison Groups]

For most craft groups, the raw mean union wages are considerably higher than for the comparison group, while the nonunion air transport means are modestly higher. Interesting are means of the BLS occupational skill index. In some cases, including the overall industry comparison to the economy-wide comparison group, the skill index mean for the air transport and comparison groups are highly similar. Where the skill values are similar, the suggestion is that the comparison group is closely matched to the air transport treatment group. Where there is a difference, it illustrates the potential importance of the skill index control for more precise estimates of wage differentials. For example, aircraft mechanics (engine and non-engine) have higher occupational skill ratings than do the other mechanics with whom 
they are compared. Apart from pilots and flight attendants, who have unique CPS occupation codes, mean values of Skill are not identical for union and nonunion workers within a craft, since craft groups can include more than one CPS occupation (e.g., mechanics include aircraft engine mechanics, aircraft mechanics excluding engine, and mechanic supervisors) and union and nonunion workers need not be equally distributed across these detailed occupations.

\section{Earnings Differential Estimates in the Air Transport Industry and by Airline Craft}

In this section, earnings differential estimates between air transport workers and "comparable” workers and levels of work economy-wide are examined. The results are presented in Table 2, first the differentials for the entire air transportation industry and then for each airline worker group. Estimates of $d$ are presented separately for union and nonunion workers and from earnings equations with and without inclusion of the BLS skill index. Estimates are for the entire 1995-2006 period, since sample sizes by year and by craft are too small to reliably identify year-to-year movements. Appendix Table 3 provides information identical to that shown in Table 2, except that results are estimated for the years 2003-2006 rather than 1995-2006. The reason for showing estimates beginning in 2003 is a change that year in CPS occupation and industry definitions (the switch from 1990 to 2000 Census codes). Because of similarity in results, discussion is restricted to Table 2, apart from noting that small sample sizes for the 2003-2006 estimates reduce their reliability, particularly for the individual crafts.

It is worth emphasizing that our CPS analysis includes only wages and salaries and not benefits. Economy-wide, unionized workers realize a "benefits premium” that is larger than the wage premium (Freeman 1981). In the airline industry, union contracts among the major airlines provide benefit levels well beyond those seen economy-wide for full-time workers in the private sector (Wachter 2004). As evident in Table 1, the overall skill index rating for workers within the airline industry is nearly identical to that seen for the economy-wide comparison group $(1,274$ versus 1,282$)$. This makes the comparison of benefits among a major carrier (e.g., United) with the average economy-wide particularly relevant, even though it lacks worker and job controls. Were it possible to estimate a total compensation differential within a regression framework (i.e., with controls), the strong suggestion is that compensation premiums 
would exceed the wage premiums presented in Table $2 .^{21}$

\section{[INSERT TABLE 2 HERE, Caption: CPS Log Wage Differentials by Craft and Union Status]}

\subsection{Industry Differentials}

The top line of Table 2 contains the earnings differential results for the air transport industry over the combined 1995-2006 period, separately by union status and both with and without inclusion of $\ln S k i l l$. The industry differential $d$ is the weighted average across wage differentials estimated for the five airline craft groups and a remaining “Other” air transport workers group.

The “standard" log wage differential $d$ for 1995-2006, compiled from estimated wage gaps absent control for Skill, is .13 log points. ${ }^{22}$ The "expanded” earnings differentials, compiled from regressions that control for Skill, reduce $d$ by .02 log points, from .13 to .11 . The smaller expanded gap estimate reflects not only that airline occupations tend to have somewhat higher skill (and other job attribute) ratings than do comparison group workers, but also that these higher skills are not fully accounted for by CPS measures such as schooling and potential experience.

The average differential across all air transport workers masks what are large earnings premiums for union workers and little apparent earnings advantage for nonunion workers. Our preferred measure of $d$ is the expanded measure, which controls for Skill. Nonunion air transport workers have an estimated $d$ of only .02, indicating that nonunion earnings in the industry are roughly comparable to earnings realized by similar workers (union and nonunion) performing comparable levels of work outside the industry. By contrast, union air transport workers realize a substantial earnings premium of .23 log points, well above the level dictated by comparability and a competitive labor market. ${ }^{23}$

A sizable share of the air transport sample (in particular the nonunion sample) is in the "Other" category, which includes workers in a wide range of occupations and some working for air transport

\footnotetext{
${ }^{21}$ A minor caveat is that our CPS economy-wide sample of full-time workers excludes those with schooling less than a high school and greater than a masters degree, while the BLS benefits sample makes no such restriction. ${ }^{22}$ All differentials are presented as log point wage gaps. Percentage gap estimates can be obtained by [ $\left.\mathrm{e}^{\mathrm{d}}-1\right] 100$, where $d$ is the log point gap. For reasons of space and because sample sizes are large, standard errors are not presented. Standard errors for the industry gaps are approximately .007. Standard errors vary across craft group, but are approximately .015 (but somewhat larger for fleet service and smaller for "other" workers).

${ }^{23}$ The airline union wage advantage is higher, but the same order of magnitude, than are economy-wide unionnonunion wage gaps during this period (Hirsch and Macpherson 2006, Table 2a). Note that the union airline differential compares unionized air transport workers to a mix of union and nonunion non-airline workers.
} 
companies other than airlines. In general, these workers tend to have smaller wage advantages than do the traditional airline crafts. If the weighted average is constructed from just the five "craft" groups (the row labeled “Industry Crafts” in Table 2), higher estimates of $d$ are obtained - a combined union and nonunion earnings advantage (controlling for Skill) of .15, a union premium of .25, and a nonunion differential of .04. In short, the air transportation industry is a high wage industry, with earnings premiums concentrated among union workers, particularly workers in the standard airline craft groups.

\subsection{Pilots}

Earnings differential estimates by airline worker group are included in Table 2. Pilots are first examined. The CPS pilot category includes “aircraft pilots and flight engineers” (pre-2003 the occupation is labeled "airplane pilots and navigators”). The comparison group for pilots includes fulltime workers outside the air transportation industry in occupations within the following broad categories beginning in 2003: business and financial operations, computer and mathematical, architecture and engineering, and life, physical science, and social science occupations. Pre-2003, the categories are labeled professional specialty occupations (except health) and technologists and technicians (except health). As for all the comparison group samples, workers with less than a high school education or a degree beyond a masters are excluded.

The largest earnings premiums for any airline craft group are found for union pilots. Absent control for the BLS skill index, the earnings differential for all pilots is .290; with lnSkill included as a control the differential is .245. The earnings premium (with Skill included) is driven principally by unionized pilots, estimates of $d$ for union pilots being a sizable .365 and for nonunion pilots being .013 , effectively zero (corresponding estimates without the Skill control are .407 and .066). There are no doubt some unmeasured differences in skill and experience between union and nonunion pilots, the latter more likely to have less flying experience and to pilot smaller planes. Having said that plane size differs, however, it is not clear how large rate differentials with respect to aircraft size would be in a competitive labor market. Whatever those differences, they could not account for such large earnings premiums. ${ }^{24}$

\footnotetext{
${ }^{24}$ Reinforcing the finding of a large earnings premium for unionized pilots is the evidence that union pilots at the
} 
Finally, it is important to note that estimates of pilot earnings differentials are sensitive to the assumed level of mean earnings above top-coded weekly earnings. As stated previously, pilots' mean earnings above the cap have been "conservatively" assigned as being equal to 1.25 times the top-code amount. This compares to the approximate 1.7 times the cap for men (and 1.6 for women) based on the Pareto distribution, the multiples used for the comparison group sample (shown at www.unionstats.com). Had the Pareto distribution estimates been used for pilots, estimated earnings premiums for union pilots would be about .10 log points higher than those shown. Because annual pilot sample sizes in the CPS are not large and the number of pilots at the top-code varies quite a bit from year to year, it is difficult to reliably estimate the time pattern of changes in pilot earnings using the CPS.

\subsection{Flight Attendants}

Flight attendants earnings are compared to those of a comparison group of workers scattered across occupations within the broad categories of sales, service, and administrative support. I focus on the earnings equation results that include the BLS occupational skill index, whose inclusion lowers estimates of flight attendant earnings differentials by about .02-.03 log points. The estimate for combined union and nonunion flight attendants is an earnings premium of .18 log points. As is the case for pilots, the premium varies by union contract coverage. Unionized flight attendants realize a .22 premium, whereas nonunion flight attendants have a small earnings advantage of .07.

Several of the caveats that arise with respect to pilot earnings premium estimates do not arise for flight attendants. First, all but a few transportation attendants employed in the air transport industry are likely to work for passenger airlines, whereas pilots and some other air transport crafts are employed in air freight or some other air transport support industries. Second, neither skill requirements nor adverse working conditions systematically increase with plane size (this issue is discussed in section 5). And

major carriers have quit rates that are close to zero (Wachter 2004). No doubt a part of this low quit rate reflects the fact that wage scales for pilots have steep growth with respect to seniority, but seniority cannot be transferred across airlines with union contracts. As pilot layoffs have become common at the legacy carriers, some have been willing to "start over" at FedEx or at other carriers where greater job security is expected (Dade 2006). Although the wage is not the only determinant of the quit rate, a quit rate close to zero is hard to imagine absent a sizable premium. Economy-wide quit rates in the private sector (including part-time workers) are about 25\% annually, while for private transportation and public utilities the rate is over 15\% (U.S. BLS 2006). 
third, the entire .22 log point difference between union and nonunion flight attendants is likely to represent a premium. Although unionized flight attendants are concentrated at major carriers and nonunion flight attendants at nonunion midsize and regional carriers (Delta’s nonunion flight attendants are an exception), large airlines should be able to attract and retain productive flight attendants at wages similar to those received by nonunion workers at small airlines.

\subsection{Mechanics}

Aircraft mechanics include workers in the air transportation industry whose detailed occupations are aircraft engine mechanics, aircraft mechanics (except engine), and mechanic supervisors. The comparison group includes workers in all mechanic occupations (including supervisors) employed outside the air transportation industry. The aircraft mechanic occupations are awarded higher skill index ratings than are all other mechanic occupations; hence wage differential estimates with a control for lnSkill are substantially lower, by about .07 log points, than those excluding lnSkill. Over the 1995-2006 period, the estimate of $d$ for mechanics with the skill index (union and nonunion combined) is .11 log points, compared to a .19 estimate without the skill index. As with pilots and flight attendants, the wage premium story is really a union story. Over the entire period, the log wage premium for union aircraft mechanics (with skill included) is .22, as compared to effectively zero (.01) for nonunion aircraft mechanics. There exist skill differences (e.g., licenses to work on different planes) among aircraft mechanics within the air transport industry that are not observed. If unmeasured skills are positively correlated with union status, estimates of within-industry union-nonunion wage differences are overstated, although wage gap estimates for all mechanics need not be biased.

As with the other employee groups, a sizable wage premium for union, but not nonunion, aircraft mechanics is observed. Airlines have limited opportunity to substitute nonunion for union pilots or flight attendants when facing large within-industry wage differences. In contrast, airlines have some ability to substitute away from their unionized mechanics by outsourcing scheduled maintenance and other work to specialized companies employing licensed aircraft mechanics. Although an airline’s mechanics union will bargain to limit such substitution, the possibility of substitution should constrain the magnitude of 
union premiums among mechanics. ${ }^{25}$

\subsection{Fleet Service (Ramp) Workers}

There are a variety of ground workers, apart from mechanics, who service airplanes. These include baggage handlers, airplane cleaners (utility workers), workers who guide planes into and out of their gates, and workers who refuel airplanes. Fleet service or ramp workers category includes those who work in the air transportation industry and whose occupations are freight, stock, and material handlers; and vehicle washer and equipment cleaners. The comparison group of workers includes those employed outside the air transportation industry in the following occupational categories: non-construction laborers and freight, stock, and material handlers; garage workers; washer-cleaners; and packers.

Inclusion of the skill index has little effect on estimates of $d$ for ramp workers, the log wage gap being .11 with or without control for $\ln S k i l l .{ }^{26}$ As with other crafts, nonunion fleet service workers appear to be paid roughly their opportunity costs, with a $d$ estimate of .01 . Unionized fleet service workers realize an estimated wage premium of .22 log points. As with mechanics, carriers facing high contract rates among fleet service workers have incentive to outsource some of this work, substituting lower-cost contract workers for their own union employees.

\subsection{Reservation Agents and Stores Employees}

Airlines have a large number of customer service employees - ticket reservation agents outside of airports, ticket and gate agents within airports, and “stores” employees who oversee the recording and distribution of supplies and parts. “Agents” are defined as those employed in the air transportation industry within the following occupations: reservation and transportation ticket agent; shipping, receiving,

\footnotetext{
${ }^{25}$ When faced with a strike by mechanics in August 2005, Northwest eliminated a large share of their mechanics jobs through outsourcing and hired (in advance of the strike) replacement workers for the remaining mechanics jobs. One should be reluctant to generalize from the Northwest example. Northwest mechanics were represented by a "rebel" union (AMFA) which had unseated the IAM, in the process alienating IAM's remaining Northwest workers and Northwest's other unions. Northwest's unionized workers crossed the AMFA picket lines and allowed Northwest to continue operations despite the strike (Carey 2005). A tentative agreement was reached in October 2006, which would allow striking workers to receive limited amounts of layoff or separation pay, and for those accepting layoff status to bid on open technician positions.

${ }^{26}$ The small effect of the Skill index is not surprising, since those working in and outside the air transportation industry (i.e., the treatment and comparison groups) are drawn largely from the same Census occupations and hence are assigned the same Skill values. It seems unlikely to me that the combination of required skills and adverse working conditions in these occupations is so different that it should lead to highly disparate wages in and outside the air transportation industry.
} 
traffic clerks; stock clerk and order filler; and customer service representative. The comparison group includes workers outside the air transportation industry employed in the same occupations as above, plus those listed as other information and record clerks and as order clerks.

The combined union-nonunion wage differential estimate of $d$ is .11 with control for $\ln S k i l l$. Union-nonunion differences here are less than seen with other crafts, with a union wage advantage relative to the non-airline comparison group of .17 and a nonunion wage advantage of .06 .

\subsection{Other Air Transport Industry Workers}

The "other" or miscellaneous category of air transport workers, all those not included in the previously discussed five crafts, are distributed over a broad range of occupations. The comparison group includes the entire sample of full-time workers outside of the air transportation industry (recall that the sample excludes those with very low and high education levels and for whom the BLS skill index is not defined). Most of these air transport workers are nonunion. Inclusion of the occupational skill index has little effect on estimates of the differential (broad occupation dummies are included in the "other" earnings equation). The overall earnings differential for the "other" group of workers is .04 . This reflects an earning premium of .15 for the small union portion of the group and a zero estimate for the large nonunion group. More so than for the five airline craft groups, a nontrivial number of the air transportation industry workers in the "other” occupation category are likely to work at companies other than a passenger airline.

Taking the occupational groups as a whole, a clear pattern emerges from the earnings analysis in this section. First, there exists a sizable earnings premium among union workers in air transportation, relative to a mix of union and nonunion comparison group workers. Second, nonunion air transport workers appear to realize little premium compared to similar workers doing similar levels of work outside the industry. Although there was evidence of rent sharing among nonunion as well as union airline workers during the pre-1978 airline regulation period and in the immediate years after deregulation (Hirsch and Macpherson 2000), any remaining rents are now small. What might be labeled an airline earnings premium is for the most part a union premium. 


\section{Wage Differences across Airlines: Do Regional Airline Wages Approximate Opportunity Costs?}

In prior sections, average compensation among national carriers reported in DOT Form 41 data have been used to measure changes over time in industry labor costs, while worker data from the CPS have been examined to estimate wage differentials for union and nonunion workers throughout the air transport industry, relative to similar workers and jobs outside the industry. In this section, evidence on contractual “top rates” for airline workers across national carriers and regional airlines is reviewed. Based on this and prior evidence, a question that is explored is whether opportunity cost wage rates for major carriers might be approximated by the rates currently seen at regional airlines.

Airline contract data are not publicly available (i.e., not reported to the government), but are assembled by trade groups. The Airline Industrial Relations Conference (Air Conference) is made up of a consortium of scheduled national airlines. Each provides their labor contracts by craft to the Air Conference, which assembles contract information and terms of employment in their database. Member airlines are provided access to contract information from all participating airlines. J. Glass \& Associates (a consultancy division overseen by Ford \& Harrison, LLP) manages a Regional Airline Association database with union and nonunion contract rates and terms of employment for regional airlines.

Wage schedules for national and regional carriers, drawn from the Air Conference and Glass \& Associates databases, are provided in a December 2004 analysis by Michael Wachter (Wachter 2004), who provided expert testimony for United Airlines in their 1113(c) bankruptcy hearing. ${ }^{27}$ It's useful to recall the economic setting. In late 2004, high-cost airlines were in a serious financial situation following September 11, a recession, Internet pricing, increased price competition and rising market shares of lowcost carriers, and rising fuel prices. United had received wage concessions in 2003 following their 2002 bankruptcy filing, but were asking for further concessions to help achieve a viable business plan that would allow them to emerge from bankruptcy protection. US Airways, which had preceded United into bankruptcy, had recently obtained reduced wage scales for their employees in their bid to emerge from bankruptcy. American had earlier received concessions from their workers that allowed them to avoid

\footnotetext{
${ }^{27}$ The Wachter analysis was conducted with assistance from James Gillula of Global Insight and from me. Views expressed in this paper are my own and need not reflect those of United, Michael Wachter, or Global Insight.
} 
bankruptcy. Delta and Northwest had relatively high contract rates at this time despite prior wage concessions; these subsequently would be reduced further leading up to and following their 2005 entry into bankruptcy. A relatively "healthy” Continental was less threatened by bankruptcy, but did receive salary relief from its unions. Compared with the legacy airlines, Southwest was the anomaly in 2004 and remains so today. Although having high contractual top rates, Southwest has a smaller share of employees at its top rates, lower benefit costs, higher labor productivity, lower operating costs, lower debt, and defined contribution rather than under-funded defined benefit pension plans.

Evidence presented in Wachter (2004) allows one to compare wage rates at the major carriers to those among similar crafts at regional airlines. The analysis included two sets of United Airlines contract rates, those in force in December 2004 and those then proposed by the airline (or, in the case of pilots, rates from a tentative agreement). The existing December 2004 rates reflected pay concessions United's unions had agreed to previously in 2003. The proposed United rates were nearly identical to those implemented previously at US Airways.

In Table 3, United's post-2004 rates are compared to rates at other major airlines, at mid-size national airlines, and those at regional airlines. The significance of United's post-2004 rates is that they, along with those at US Airways, can be thought of as setting, at least for a couple of years, a new industry standard. ${ }^{28}$ It is this "standard" that is compared to wage schedules at mid-size and regional carriers.

\section{INSERT TABLE 3 HERE, Caption: Contractual Top-Rates at United and Other Carriers}

Salary schedules are provided for eight separate worker crafts, summarized in Table 3. These are pilots, flight attendants, mechanics, utility workers, ramp workers, stores employees, customer service representatives (CSR), and reservation service representatives (RSR). Recall that the CPS analysis had five airline craft groups. The first three groups in Table 3 - pilots, flight attendants, and mechanics align exactly with CPS categories. The next two - utility (cleaners) and ramp workers - were included in the CPS fleet service worker category. The next three categories - stores, CSR, and RSR employees -

\footnotetext{
${ }^{28}$ Delta and Northwest, which entered bankruptcy in 2005 with pay rates well above United, eventually implemented wage schedules similar to United's post-2004 rates. American and Continental, which received concessions from their unions outside of bankruptcy, have rates somewhat above those of United.
} 
were included in the CPS agent category.

The first two columns of Table 3 provide the top-rate salary rates by craft for United before and after December 2004. It is the post-2004 rate that will be treated as an approximation of the industry standard for major and national airlines. The next three columns present the unweighted average of rates at the six major airlines other than United (American, Continental, Delta, Northwest, Southwest, US Airways), midsize national airlines, and at regional airlines. ${ }^{29}$ The use of top rates (maximum seniority) means that what is being compared is a wage contract structure across airlines rather than payroll cost differences. At the legacy airlines, a large proportion of workers are at the top rates. Generally, the average wage within an airline will be below the top rate, although this need not be true since average wages include overtime pay and possible pay supplements (e.g., international rates for flight attendants) not included in the top rate. New or expanding airlines will have fewer workers with high seniority, hence differences in top rates across carriers may not fully reflect current payroll differences between legacy and low cost carriers. Over time, there should be a narrowing payroll cost gap as the age structure of the legacy and low cost carriers becomes more similar.

For all crafts other than pilots and flight attendants, hourly wage rates are provided. The rate for mechanics is an "all-in top rate" that includes the top step base pay and maximum license, skill, line, and longevity pay. For pilots at the major and mid-size national carriers, the pay shown is a monthly pay based on a 75 -hour yield for a $12^{\text {th }}$ year captain flying a weighted average of planes within each airline's fleet. Pilot rates at regional carriers are for a $12^{\text {th }}$ year captain flying a weighted average of 50 -seat and larger jets. Pay shown for flight attendants is likewise based on a 75-hour yield, with top-step base and incentive pay (but excluding international pay).

The last three columns of Table 3 provide the percentage differential between United's post-2004 rates of pay and the end-of-year 2004 pay in the three sectors of the airline industry - other major airlines, mid-size national airlines, and regional carriers. As evident from these columns, United’s proposed (and

\footnotetext{
${ }^{29}$ The mid-size national airlines are AirTran, Alaska, America West, ATA, Frontier, JetBlue, and Midwest. The regionals are Air Wisconsin, Allegheny, American Eagle, Atlantic Southeast, Chautuaqua, Comair, ExpressJet, Horizon, Independence, Mesa, Mesaba, MidAtlantic, Midwest Connect, Piedmont, Pinnacle, PSA, SkyWest, and Trans States. Rates were not provided for all airlines in every craft.
} 
eventual) rates for pilots, flight attendants, and, to a lesser extent, mechanics, would be below the average of other major airlines. In 2005 and 2006, rates at Delta and Northwest would decrease to a level similar to those at United. The United top rates for pilots, flight attendants, and mechanics were similar to those seen at mid-size national airlines. Rates for the remaining crafts would be similar to December 2004 rates at other major airlines and above rates at mid-size carriers.

The importance of Table 3 stems from the results reported in the final column, the difference in log wages between the United proposed wages, a stand-in for what would emerge as the national carrier “industry standard,” and the unweighted averages of up to 18 regional airlines (but fewer in some crafts). These craft-specific wage gaps are large - .59 log points (80\%) for pilots, .28 (32\%) for flight attendants, .27 (31\%) for mechanics, .30 (34\%) for utility, .36 (43\%) for ramp workers, .34 (41\%) for stores workers, and .38 (46\%) for gate agents (there are few reservation agents among the regional airlines). ${ }^{30}$

Do wages at regional airlines approximate opportunity costs? By opportunity cost wages, what is meant is a compensation structure that in a competitive labor market could in the long run attract and retain a labor force with "appropriate” skills (appropriate meaning profit-maximizing, with there being a trade-off between compensation and productivity). Wachter (2004) suggests that the wage scales seen at regional airlines provide an approximation of opportunity cost wages, based on the similarity of jobs at the major and regional carriers and small differences between regional wage scales and average published wage rates within the same broad occupation categories economy-wide.

Although this claim is difficult to establish in a rigorous manner, the thesis is plausible. The earlier CPS analysis implements comparability through the estimation of earnings models intended to compare air transport workers with measurably similar workers in broadly similar jobs outside the air transport industry. Jobs are made statistically equivalent, at least in principle, through measures of worker and job attributes. The analysis found rough equivalency between nonunion wages among craft workers in the air transportation industry and "comparable” workers outside the industry. Given high

\footnotetext{
${ }^{30}$ The stated percentage differences are calculated using the "low" regional airline average wage as the base. The log gaps (times 100) provide a value in between percentages calculated using the low and high wages as base. The log of the average wage across airlines (used in the calculation) is a little larger than the average of log wages.
} 
rates of union coverage among major carriers (Delta being the exception), then many of these nonunion workers are employed by mid-size and regional carriers, as well as air transportation companies other than certificated carriers. The CPS analysis cannot compare identical jobs, but it does approximate what airline workers might have earned in an alternative career path (i.e., long-run opportunity costs)

The regional airline comparison seen in Table 3 provides an alternative way to assess comparability. The analysis compares workers in the same (i.e., comparable) occupation within the same industry. Such a wage comparison provides a control for skills, worker preferences, and working conditions. This is an important advantage, but has the disadvantage that wages for all jobs within an industry may be impacted by non-competitive wage determination (e.g, union bargaining power), resulting in wage levels above opportunity cost. ${ }^{31}$

Although comparing wages within the industry provides a seemingly precise jobs match, it cannot be asserted that jobs and workers within the industry are literally identical. Some (unknown) portion of each of the gaps between wages at the major and at regional carriers reflects differences in worker skills or in the nature of the job. Even were there competitive wage determination throughout the airline industry, wage differences between the major and regional carriers would remain. Today’s wages at regional carriers are presumably higher than they would be were airline labor markets perfectly competitive (e.g., absent union coverage or the threat of organizing). A competitive or opportunity cost wage structure throughout the industry might produce salaries at the major carriers that are similar to or slightly above what regional carriers pay today.

How similar are workers and jobs at the major versus the regional carriers? The answer to this question will differ across craft. Clearly, pilots at major carriers are flying larger jets and typically have greater flying experience. A competitive wage structure would produce higher salaries for pilots flying larger planes and with more experience. But it does not follow that the wage gradient with respect to plane size or experience would be as large as is evident today, or that current salaries at regional carriers would not be sufficient to attract to major carriers a sufficient number of pilots skilled at flying large jets.

\footnotetext{
${ }^{31}$ In particular, the concern is that union power in the industry (both union coverage and the threat of organizing uncovered workers) raises the level of nonunion wages and regional carrier wages to exceed opportunity costs.
} 
Pilots are highly skilled and there is considerable trust placed on pilots not to make errors. But competitive salaries are determined at the margin and there are large numbers of individuals who want to be pilots - and who are able and willing to acquire the skills necessary to be a pilot. ${ }^{32}$ Regional airlines are able to attract qualified applicants, even where the possibility of moving to a major carrier at far higher pay is low. A high proportion of these pilots could and would acquire the licensing to fly larger planes were such jobs available. Nothing in the analysis permits us to say that a competitive salary for pilots of large jets would be precisely at the pay level seen today for regional jets. But we know that current levels of pay at major carriers (as seen in the .59 log wage premium for major carriers over regional carriers) far exceed the compensation necessary to attract and retain qualified pilots. And we know from the CPS analysis that unionized pilots (averaged across the entire air transport industry, including regionals and freight carriers) realize substantial earnings premiums, .37 log points, relative to what they might have earned in alternative career paths. Thus, salaries seen today for regional pilots may well be a reasonable approximation of what average salaries would be for airline pilots across a competitive airline industry labor market.

It is worth noting that a fully competitive labor market would allow movement of pilots and other workers across carriers, without placing workers at a starting wage scale (zero seniority). ${ }^{33}$ If an industry were such that most worker skills were firm specific (i.e., not valued at other firms), then we would expect there to be promotion from within and little hiring at other than a junior level. Yet far more than in most industries, worker skills in the airline industry are highly transferable across firms. The skills of a pilot (or flight attendant or mechanic) that are valued at one airline are also valued at other airlines. What makes airline skills difficult to transfer and minimizes cross-carrier mobility of airline workers are not differences in skill requirements, but provisions in union contracts that strictly tie pay to seniority with one’s current employer. Absent worker mobility across carriers, we cannot know what would be a

\footnotetext{
${ }^{32}$ Ideally, we would like to measure applicant queues and turnover at regional carriers to help determine if wages are at market clearing levels. Currently, there is an excess supply of pilots throughout the industry. During 2005 FedEx had 14,000 applications for the 420 pilot jobs it filled. UPS hired 233 pilots from among 10,000 applicants, 8,000 of whom were passenger pilots (Dade 2006).

${ }^{33}$ Defined benefit pension plans also reduce mobility across firms, but these are becoming increasingly rare for new private sector workers.
} 
competitive wage structure. Mobility would act to limit demands for "high” pay since carriers can hire experienced workers from other carriers. Likewise, mobility would limit the ability of financially strapped carriers to pay below opportunity cost wages, since workers could move to other carriers.

Flight attendant pay is approximately .28 log points higher at major carriers than at the regionals. The principal difference between the two jobs is that flight attendants at the majors work on larger planes, work in teams rather than solo, and service longer but fewer flights. It is not at all clear that the differences in required skills and the desirability of working conditions between working on a large jet versus a small plane should lead to higher pay at the major carriers. Many (but not all) flight attendants will prefer to work as part of a team and to service longer but fewer flights. Some flight attendants will prefer the more limited range of travel typical of regional airlines; while others will prefer the wider range of travel to larger cities, both in the U.S. and abroad. If regional airlines can readily attract and retain flight attendants at their current levels of pay, absent the expectation that they will move to higher paying job at a major carrier, then it is reasonable to argue that competitive pay for flight attendants would not be higher (or substantially higher) than the pay seen today at the regional carriers. The .22 log point CPS wage premium estimated for union flight attendants (and .18 for all flight attendants) reinforces the argument that wage scales at regional carriers roughly approximate opportunity costs.

As with pilots, one would expect to see aircraft mechanics who service larger planes and work at major carriers to be paid more than mechanics at regional carriers. But it does not follow that competitive differentials between rates at major and regional carriers need be $31 \%$ for mechanics (as in Table 3 ). The estimated CPS premium for union aircraft mechanics relative to other types of mechanics economy-wide (conditional on schooling, age, and the occupational skill index, which highly rated aircraft mechanics) is .22 log points. If the CPS estimate is correct, then it suggests that competitive wage rates for aircraft mechanics should be lower throughout the industry, with a smaller wage gap between the regional and major carriers.

The remaining airline crafts - ground workers (ramp and utility employees), agents, and stores employees - receive wage rates .30 to .38 log points higher at the major airlines than at regional airlines. 
The CPS premium for union workers in these occupations was about .20 log points. Although there are some differences in the nature of these jobs between large and small carriers, the requisite skills and working conditions should not require such substantial wage differentials as seen in Table 3. Obviously, competitive wage levels across the entire industry would not precisely equal what is seen today at regional airlines, but these levels might not be too bad an approximation.

In short, both the CPS analysis, comparing unionized workers throughout the air transport industry with similar workers and levels of job skill outside the airline industry, and the within industry comparison of contract scales at the majors and the regional carriers, indicate a wage structure in the airline industry that is well above opportunity cost. Were the labor market in the airline industry a competitive one, absent unions that possessed and exercised strong bargaining power, we would see a substantially lower level of compensation in the industry, coupled with easy worker mobility across carriers and few contractual restrictions on outsourcing. Whether airline compensation is headed toward opportunity costs is addressed in the final section of the paper.

\section{The Future - Opportunity Cost Wages or Union Wage Cycling?}

Workers in the air transportation industry are relatively highly paid. Some of this high pay reflects the training and skills required for jobs in the airline industry. Analysis in this paper, however, provides evidence of substantial wage premiums in the air transportation industry. The premiums are realized primarily by union employees at major and mid-size airlines. Wages at regional carriers are substantially lower than at large national carriers and may roughly approximate what would be opportunity cost earnings for the rest of the airline industry. There is little evidence for earnings premiums among nonunion workers in the industry, many of whom work in occupations outside the traditional airline craft groups - pilots, flight attendants, mechanics, fleet service, and agents. Pay premiums are particularly large for unionized pilots, but are also substantial for other union craft workers.

Compensation premiums are tied closely to union bargaining power (i.e., the ability to inflict costs through a strike), a strike threat power that appears unparalleled in private industry in the U.S. Union ability to acquire wage gains, however, depends crucially on the financial health of carriers. 
During good times, unions capture or "tax" some sizable share of potential profits. During bad times, unions moderate these demands or agree to wage concessions when firm survival and jobs are threatened. Because wages and benefits are negotiated and specified in long-term contracts, but the future financial fortunes of the firm are sometimes poorly predicted, changes in compensation (either through new contracts or renegotiation of contracts) lag changes in the product market.

What might stop or substantially weaken this lagged wage-profit cycling (i.e., a variable union tax on carrier profits)? In most U.S. industries, such cycles are not readily evident because union density is low and competition forces product prices to approximately reflect opportunity costs (including a normal return on capital). Were there a sufficient number of carriers that had competitive or opportunity cost compensation and were air fares not determined in partially segmented markets, pricing would consistently reflect the costs at these low-cost carriers. There would be little ability for unions to acquire and sustain noncompetitive wages and benefits. Certainly the airline industry is not immune to such forces. Increased penetration of low-cost carriers has limited the pricing power of major carriers, particularly on heavily traveled point-to-point routes. ${ }^{34}$ There also exists competition across cities (carriers) when customers prove willing to drive to alternative airports (Fournier et al., forthcoming). And during time periods and in markets with excess capacity, price competition can be keen. ${ }^{35}$

The bankruptcies of major carriers and concomitant downward adjustment in labor compensation throughout much of the industry can certainly be seen as a move toward a more competitive wage structure. The increased penetration of low cost carriers and the enhanced competition within major city hub airports suggests that price competition will constrain the future growth in labor costs. But I would not predict an imminent or smooth transition to an era of opportunity cost compensation. The airline industry remains highly unionized. As in the past, airlines are likely to reestablish market positions where

\footnotetext{
${ }^{34}$ Low-cost carriers, however, have low penetration in low density origin-to-destination routes, which continue to depend heavily on the hub-based legacy carriers. Analysis by Darin Lee shows that lower cost carriers' share of domestic passengers increased from about 10\% in 1990 to about 30\% in 2004. He also estimates that by 2004, 75\% of domestic passenger "trips" were exposed to LCC competition. See http://www.darinlee.net/stats.html.

${ }^{35}$ Busse (2002) finds that carriers in the worse financial condition, particularly those highly leveraged, are most likely to start price wars. Carriers which most directly compete with price war leaders are more likely to join the price war.
} 
they can be profitable, possibly through innovations or in other ways that cannot be anticipated. As this is written, airlines appear to be close to a point of solvency due to healthy demand and reduced capacity. If fuel prices moderate and seating capacity remains tight, airlines will resume profitability.

Then the test begins. Unions retain substantial bargaining power and will attempt to make up for wage and benefit concessions. How this bargaining will play out is hard to predict, but it seems unlikely that airlines can hold compensation down to the levels acquired in 2005-2006. Of course, the major carriers and their unions will not return quickly to the types of contracts seen in the early 2000s. It is clear to companies and their unions that such rates cannot be sustained. Union demands will be less affected by the opportunity cost of labor than by carriers' ability to pay. It is unclear whether or not demands well in excess of opportunity costs will be or can be rejected by management. ${ }^{36}$ For the foreseeable future at least, airline unions will continue to tax carrier profits and we shall see a continuation of union wage cycling, hopefully at levels more sustainable than in the past.

The labor relations environment in the airline industry has long been contentious and characterized by mutual distrust. ${ }^{37}$ The bankruptcies at US Airways, United, Delta, and Northwest, along with labor concessions at American, Continental, and several smaller airlines, have further strained management-labor relations. ${ }^{38}$ There are mutual benefits to a more cooperative labor relations environment, if it can produce a high level of productivity and sustainable labor costs. Although there is little reason to expect such an outcome, there are at least some forces that might push in that direction. The financial troubles at major and mid-size carriers, coupled with increasing product market competition, make unions and their members more aware than ever that their long-run well-being requires

\footnotetext{
${ }^{36}$ An interesting example of such a dynamic can be seen at (largely nonunion) FedEx, which is currently highly profitable. At the same time that pilot salaries have fallen in the passenger airline industry, pilots at FedEx have emphasized their company's profitability and pushed for large pay increases. A lengthy impasse began in 2004, and remained unresolved until a tentative agreement was reached in August 2006 (their 1999 contract remained in force during this period). Similarly, a new UPS pilots' contract was ratified in August 2003 (the prior contract became amendable at the end of 2003). The new contract, which runs through 2011, includes substantial pay increases. Pay scales for senior pilots at the cargo carriers now exceed those for the major carriers. Some employed passenger pilots, concerned about job security at their current employers, have attempted to "start over" at UPS or FedEx, despite their loss of seniority and a large initial sacrifice in pay (Dade 2006).

${ }^{37}$ Exceptions include Southwest Airlines and recent labor relations at Continental. For a discussion, see Gittell, von Nordenflycht, and Kochan (2004).

${ }^{38}$ Survey evidence in 2005 indicates high levels of anger and militancy among pilots and flight attendants (Comstock 2006).
} 
a financially healthy employer. At the same time, Southwest and, to a lesser extent, Continental, provide examples where relatively cooperative labor relations environments are possible and jointly beneficial.

Although it is possible that labor relations at the legacy carriers will improve, this is just a possibility. Nothing guarantees that such environments will emerge, or even that cooperative labor relations can be maintained at Southwest or elsewhere in the industry. What can be predicted is that absent the emergence of more cooperative labor relations environments, we are likely to observe a return to wage and profit cycles, increased penetration of carriers that can achieve and maintain low costs (a function of productivity as well as labor compensation), and an uncertain future for the remaining legacy airlines. Whatever the labor relations path followed in the airline industry, all parties must continue to respond to the competitive forces that have been and will continue to ultimately shape the direction of the industry. 


\section{References}

Air Transport Association. 2006. U.S. Airline Cost Index: Major \& National Passenger Carriers, Fourth Quarter 2005, Washington, DC, July 14, http://www.airlines.org/economics/finance/CostIndex.htm.

Allegretto, S.A., Corcoran, S.P., Mishel, L. 2004. How does teacher pay compare? Methodological challenges and answers. Washington, DC: Economic Policy Institute.

Bollinger, C.R., Hirsch, B.T. 2006. Match bias from earnings imputation in the CPS: The case of imperfect matching. Journal of Labor Economics 24 (3), 483-519.

Busse, M. 2002. Firm financial condition and airline price wars. RAND Journal of Economics 33 (2), 298318.

Cahuc. P., Zylberberg, A. 2004. Labor Economics. Cambridge, Mass:The MIT Press.

Card, D. 1998. Deregulation and labor earnings in the airline industry. In Regulatory Reform and Labor Markets, edited by J. Peoples. Norwell, Mass: Kluwer Academic Publishing, 183-230.

Carey, S. 2005. Northwest, striking mechanics are to meet on talks. Wall Street Journal, October 12, p. B5.

Comstock, P. 2006. Work-related views of pilots and flight attendants: Turbulence ahead? Perspectives on Work (The magazine of the LERA) 9 (2), 57-59.

Crémieux, P. 1996. The effect of deregulation on employee earnings: Pilots, flight attendants, and mechanics, 1959-1992. Industrial and Labor Relations Review 49 (2), 223-42.

Dade, C. 2006. Why some passenger pilots take huge pay cuts to fly cargo. Wall Street Journal, June 2, p. A13.

Freeman, R.B. 1981. The effect of unionism on fringe benefits. Industrial and Labor Relations Review 34 (4), 489-509.

Fournier, G.M., Hartmann, M.E., Zuehlke T. forthcoming. Airport substitution by travelers: Why do we have to drive to fly? In Advances in Airline Economics, Volume II: The Economics of Airline Institutions, Operations and Marketing, edited by D. Lee, Amsterdam: Elsevier.

Gittell, J.H., von Nordenflycht, A., Kochan, T.A., 2004. Mutual gains or zero sum? Labor relations and firm performance in the airline industry. Industrial and Labor Relations Review 57 (2), 163-180.

Hirsch, B.T., Schumacher, E.J., 2004. Match bias in wage gap estimates due to earnings imputation. Journal of Labor Economics 22 (3), 689-722.

Hirsch, B.T., Macpherson, D.M. 2000. Earnings, rents, and competition in the airline labor market. Journal of Labor Economics 18 (1), 125-55.

Hirsch, B.T., Macpherson, D.M. 2003. Union membership and coverage database from the Current Population Survey: Note. Industrial and Labor Relations Review 56 (2), 349-54 (accompanying database at http://www.unionstats.com, updated annually).

Hirsch, B.T., Macpherson, D.M. 2006. Union Membership and Earning Data Book: Compilations from the Current Population Survey (2006 Edition). Washington, DC: The Bureau of National Affairs.

Johnson, Nancy Brown. 1995. Pay levels in the airlines since deregulation. In Airline Labor Relations in the Global Era: The New Frontier, edited by P. Cappelli. Ithaca, NY: ILR Press, 101-15.

Matsa, D.A. 2006. Capital structure as a strategic variable: Evidence from collective bargaining. Working paper, September 28. Available at SSRN: http://ssrn.com/abstract=933698. 
Nay, L.A. 1991. The determinants of concession bargaining in the airline industry. Industrial and Labor Relations Review 44 (2),307-23.

Pierce, B. 1999. Using the National Compensation Survey to predict wage rates. Compensation and Working Conditions (Winter), 8-16.

U.S. Bureau of Labor Statistics. 2006. Job openings and labor turnover: April 2006. News Release, Table 8, at http://www.bls.gov/news.release/jolts.toc.htm.

Wachter, M.L. 2004. Declaration and Expert Report of Michael L. Wachter. Exhibit 103, in the United States Bankruptcy Court for the Northern District of Illinois, Eastern Division, In re Chapter 11, UAL Corporation, et al., Case No. 02-B-48191, December. 
Fig. 1: Airline Wages and Benefits, Level and Dispersion, 1990-2005

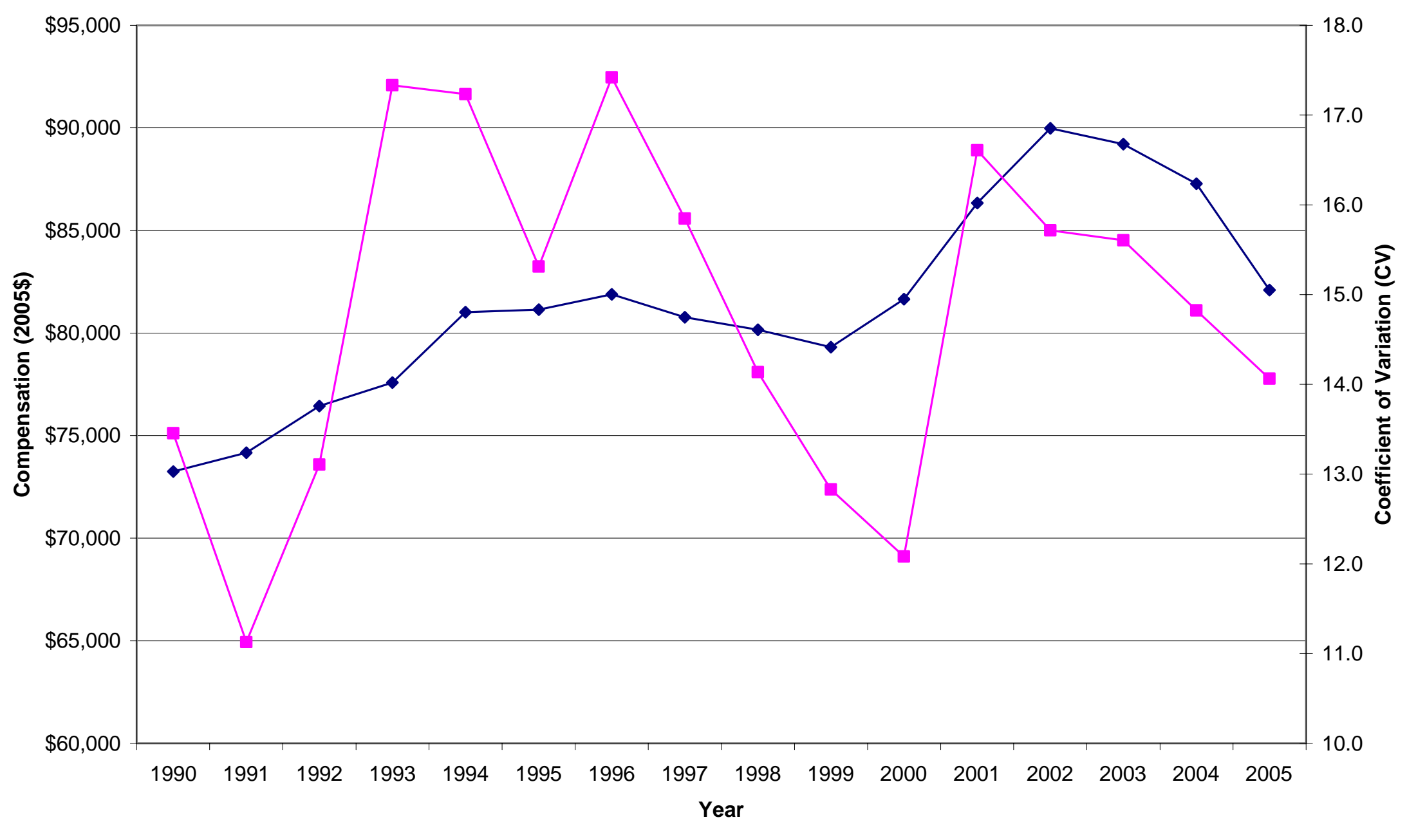

$\rightarrow-$ Compensation $\rightarrow-$ Coefficient of Variation (CV)

Compiled from figures reported by U.S. Department of Transportation, Bureau of Transportation Statistics, Form 41 . See Appendix Table 1 and text for a listing of the numbers and further details. 
Fig. 2: Labor Costs and CV Per Available Seat Mile, 1990-2005

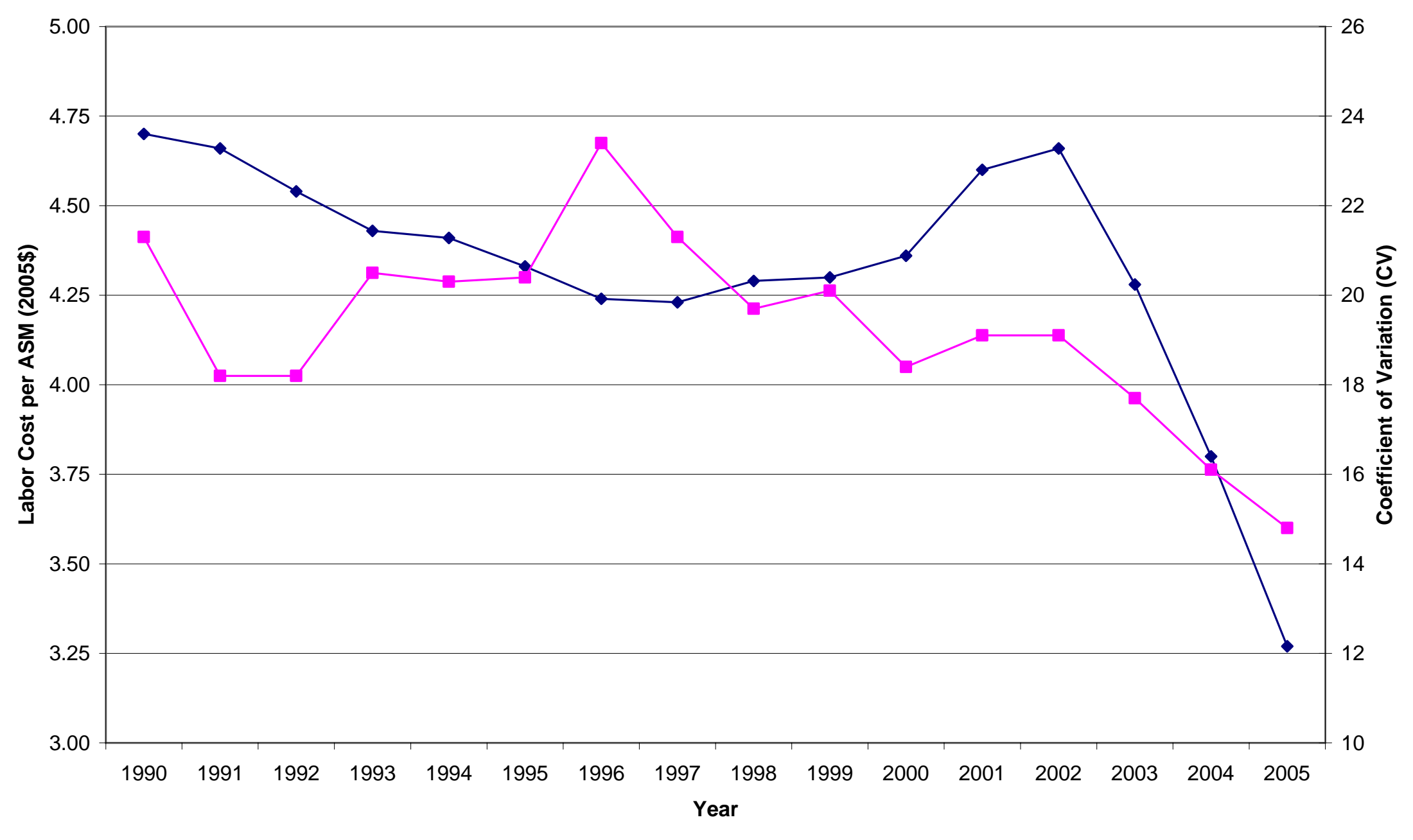

$\neg$ Labor Costs per ASM $\rightarrow$ Coefficient of Variation (CV)

Compiled from figures reported by U.S. Department of Transportation, Bureau of Transportation Statistics, Form 41. See Appendix Table 1 and text for a listing of the numbers and further details. 
Table 1: CPS Mean Wages (2005\$) and Skill Index, by Airline Craft and Comparison Groups

\begin{tabular}{|c|c|c|c|c|}
\hline 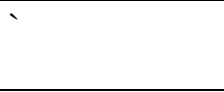 & $\begin{array}{l}\text { All Airline } \\
\text { Workers }\end{array}$ & Union & Nonunion & $\begin{array}{l}\text { Comparison } \\
\text { Groups }\end{array}$ \\
\hline \multicolumn{5}{|l|}{ Industry } \\
\hline Wage & $\$ 22.88$ & $\$ 27.03$ & $\$ 19.68$ & $\$ 19.29$ \\
\hline Skill Index & 1,274 & 1,241 & 1,299 & 1,282 \\
\hline $\mathrm{N}$ & 6,835 & 2,971 & 3,864 & 877,302 \\
\hline \multicolumn{5}{|l|}{ Pilots } \\
\hline Wage & $\$ 43.09$ & $\$ 49.38$ & $\$ 30.86$ & $\$ 27.30$ \\
\hline Skill Index & 2,225 & 2,225 & 2,225 & 1,864 \\
\hline $\mathrm{N}$ & 879 & 580 & 299 & 76,702 \\
\hline Weight & 0.125 & 0.197 & 0.072 & \\
\hline \multicolumn{5}{|c|}{ Flight Attendants } \\
\hline Wage & $\$ 21.24$ & $\$ 22.09$ & $\$ 18.99$ & $\$ 15.56$ \\
\hline Skill Index & 933 & 933 & 933 & 896 \\
\hline $\mathrm{N}$ & 893 & 648 & 245 & 278,593 \\
\hline Weight & 0.134 & 0.219 & 0.070 & \\
\hline \multicolumn{5}{|l|}{ Mechanics } \\
\hline Wage & $\$ 23.73$ & $\$ 26.58$ & $\$ 20.84$ & $\$ 18.75$ \\
\hline Skill Index & 1,577 & 1,578 & 1,577 & 1,204 \\
\hline $\mathrm{N}$ & 924 & 465 & 459 & 36,419 \\
\hline Weight & 0.131 & 0.156 & 0.112 & \\
\hline \multicolumn{5}{|l|}{ Fleet Service } \\
\hline Wage & $\$ 15.38$ & $\$ 17.67$ & $\$ 13.49$ & $\$ 12.85$ \\
\hline Skill Index & 508 & 446 & 560 & 437 \\
\hline $\mathrm{N}$ & 343 & 155 & 188 & 16,050 \\
\hline Weight & 0.042 & 0.046 & 0.038 & \\
\hline \multicolumn{5}{|l|}{ Agents } \\
\hline Wage & $\$ 16.41$ & $\$ 17.84$ & $\$ 15.32$ & $\$ 13.69$ \\
\hline Skill Index & 733 & 727 & 737 & 661 \\
\hline $\mathrm{N}$ & 1,203 & 523 & 680 & 14,682 \\
\hline Weight & 0.175 & 0.157 & 0.189 & \\
\hline \multicolumn{5}{|l|}{ Other } \\
\hline Wage & $\$ 20.23$ & $\$ 21.55$ & $\$ 19.83$ & $\$ 19.29$ \\
\hline Skill Index & 1,312 & 1,019 & 1,400 & 1,282 \\
\hline $\mathrm{N}$ & 2,643 & 609 & 2,034 & 877,302 \\
\hline Weight & 0.393 & 0.225 & 0.520 & \\
\hline
\end{tabular}

Means are compiled from the CPS monthly earnings files, September 1995 through May 2006. Wages, shown in 2005\$, measure the hourly earnings for non-flight personnel, calculated over the sample (of size N) excluding imputed earners. For flight personnel, wages are calculated based on weekly earnings and an assumed 40 hour week for pilots and 36 hour week for flight attendants. The airline and comparison worker groups are described in the text. The BLS Skill index points are described in text and in Pierce (1999). Group weights, calculated from CPS employment weights for the CPS sample including imputed earners, are used to compile the overall industry and combined craft wage differentials shown in Table 2. 
Table 2: CPS Log Wage Differentials by Airline

Worker Group and Union Status, 1995-2006

\begin{tabular}{|c|c|c|c|c|}
\hline Group & $\begin{array}{l}\text { Skill Index } \\
\text { Included }\end{array}$ & All & Union & Nonunion \\
\hline \multicolumn{5}{|c|}{ All Industry } \\
\hline & No & 0.130 & 0.249 & 0.040 \\
\hline & Yes & 0.108 & 0.226 & 0.019 \\
\hline \multicolumn{5}{|c|}{ Industry Crafts } \\
\hline & No & 0.189 & 0.283 & 0.072 \\
\hline & Yes & 0.154 & 0.249 & 0.037 \\
\hline \multicolumn{5}{|l|}{ Pilots } \\
\hline & No & 0.290 & 0.407 & 0.066 \\
\hline & Yes & 0.245 & 0.365 & 0.013 \\
\hline \multicolumn{5}{|c|}{ Flight Attendants } \\
\hline & No & 0.209 & 0.246 & 0.110 \\
\hline & Yes & 0.182 & 0.224 & 0.070 \\
\hline \multicolumn{5}{|c|}{ Mechanics } \\
\hline & No & 0.189 & 0.297 & 0.080 \\
\hline & Yes & 0.115 & 0.223 & 0.005 \\
\hline \multicolumn{5}{|c|}{ Fleet Service } \\
\hline & No & 0.114 & 0.220 & 0.008 \\
\hline & Yes & 0.112 & 0.219 & 0.006 \\
\hline \multicolumn{5}{|c|}{ Agents } \\
\hline & No & 0.118 & 0.182 & 0.069 \\
\hline & Yes & 0.107 & 0.171 & 0.058 \\
\hline \multicolumn{5}{|l|}{ Other } \\
\hline & No & 0.038 & 0.132 & 0.010 \\
\hline & Yes & 0.036 & 0.147 & 0.003 \\
\hline
\end{tabular}

See note to Table 1. Estimates are based on the CPS monthly earnings files, September 1995 through May 2006. The "Industry Crafts" group includes the five airline crafts but excludes "Other", while "All Industry" includes "Other" as well. The "All Industry" and "Industry Craft" differentials are compiled based on the weighted average of their component parts, using the employment weights shown in Table 1 (with separate weights by union status). Estimation of differentials explained in text. Differentials are shown with and without control for BLS occupational skill index, lnSkill. Other control variables are education dummies (5) reflecting levels from a minimum of a high school degree (including a GED) through a masters degree, potential experience in quartic form separately and interacted with gender, gender, race/ethnicity (4), foreign born, region (8), metropolitan area size (6, with non-metro the base), year dummies (10), and broad occupation dummies (11, included only for the "Other" group regression). 
Table 3: Contractual Top-Rates and Log Wage Differentials between United Airlines and Major, Mid-Size, and Regional Carriers, December 2004

\begin{tabular}{|c|c|c|c|c|c|c|c|c|}
\hline Employee Group & $\begin{array}{c}\text { United Airlines } \\
\text { Dec } 2004\end{array}$ & $\begin{array}{c}\text { United Proposal } \\
\text { Dec } 2004\end{array}$ & $\begin{array}{c}\text { Average at } \\
\text { Majors }\end{array}$ & $\begin{array}{c}\text { Average at } \\
\text { Mid-size }\end{array}$ & $\begin{array}{c}\text { Average at } \\
\text { Regionals }\end{array}$ & $\begin{array}{c}\text { United } \\
\text { Post-2004 } \\
\text { vs. Majors }\end{array}$ & $\begin{array}{c}\text { United } \\
\text { Post-2004 } \\
\text { vs. Mid-size }\end{array}$ & $\begin{array}{c}\text { United } \\
\text { Post-2004 } \\
\text { vs. Regionals }\end{array}$ \\
\hline Pilots (monthly) & $\$ 12,374$ & $\$ 10,554$ & $\$ 12,627$ & $\$ 11,311$ & $\$ 5,861$ & -0.179 & -0.069 & 0.588 \\
\hline FAs (monthly) & $\$ 3,073$ & $\$ 2,895$ & $\$ 3,447$ & $\$ 2,863$ & $\$ 2,198$ & -0.175 & 0.011 & 0.275 \\
\hline Mechanics & $\$ 31.09$ & $\$ 29.82$ & $\$ 31.99$ & $\$ 28.39$ & $\$ 22.73$ & -0.070 & 0.049 & 0.271 \\
\hline Utility & $\$ 17.50$ & $\$ 16.65$ & $\$ 16.83$ & $\$ 13.49$ & $\$ 12.39$ & -0.011 & 0.210 & 0.296 \\
\hline Ramp & $\$ 21.06$ & $\$ 19.61$ & $\$ 20.09$ & $\$ 17.05$ & $\$ 13.69$ & -0.024 & 0.140 & 0.359 \\
\hline Stores & $\$ 21.06$ & $\$ 19.61$ & $\$ 19.86$ & $\$ 16.82$ & $\$ 13.93$ & -0.013 & 0.153 & 0.342 \\
\hline CSR & $\$ 21.75$ & $\$ 20.25$ & $\$ 20.31$ & $\$ 16.86$ & $\$ 13.82$ & -0.003 & 0.183 & 0.382 \\
\hline RSR & $\$ 21.01$ & $\$ 19.56$ & $\$ 19.58$ & $\$ 15.95$ & N/A & -0.001 & 0.204 & N/A \\
\hline
\end{tabular}

The dollar rates are reported in Wachter (2004). The United proposed wages are treated as a rough approximation of prevailing wages at the major carriers following wage concessions at major airlines during 2005 and 2006. The last three columns show the difference in log of the average wages between the United proposal and the respective averages at the majors, mid-size, and regional airlines. All wages shown reflect top-rates (maximum seniority). For pilots and flight attendants, monthly rates are based on a 75-hour yield. Other rates shown are hourly rates. RSR (reservation service representatives) are not employed by most regional carriers. Averages at six major carriers (excluding United), mid-size, and regional airlines are unweighted. Discussion and a list of included carriers are provided in the text. 


\begin{tabular}{|c|c|c|c|c|}
\hline \multicolumn{5}{|c|}{$\begin{array}{c}\text { Appendix Table 1: } \\
\text { Average Compensation and Labor Costs per Available } \\
\text { Seat Mile, Major and National Airlines, 1990-2005 }\end{array}$} \\
\hline Year & $\begin{array}{c}\text { Salaries and } \\
\text { Benefits }(2005 \$)\end{array}$ & CV & $\begin{array}{l}\text { Labor Costs, } \\
\text { cents per ASM } \\
(2005 \$)\end{array}$ & CV \\
\hline 1990 & $\$ 73,244$ & 13.5 & 4.70 & 21.3 \\
\hline 1991 & $\$ 74,164$ & 11.1 & 4.66 & 18.2 \\
\hline 1992 & $\$ 76,447$ & 13.1 & 4.54 & 18.2 \\
\hline 1993 & $\$ 77,586$ & 17.3 & 4.43 & 20.5 \\
\hline 1994 & $\$ 81,012$ & 17.2 & 4.41 & 20.3 \\
\hline 1995 & $\$ 81,147$ & 15.3 & 4.33 & 20.4 \\
\hline 1996 & $\$ 81,893$ & 17.4 & 4.24 & 23.4 \\
\hline 1997 & $\$ 80,764$ & 15.8 & 4.23 & 21.3 \\
\hline 1998 & $\$ 80,156$ & 14.1 & 4.29 & 19.7 \\
\hline 1999 & $\$ 79,318$ & 12.8 & 4.30 & 20.1 \\
\hline 2000 & $\$ 81,656$ & 12.1 & 4.36 & 18.4 \\
\hline 2001 & $\$ 86,339$ & 16.6 & 4.60 & 19.1 \\
\hline 2002 & $\$ 89,984$ & 15.7 & 4.66 & 19.1 \\
\hline 2003 & $\$ 89,213$ & 15.6 & 4.28 & 17.7 \\
\hline 2004 & $\$ 87,279$ & 14.8 & 3.80 & 16.1 \\
\hline 2005 & $\$ 82,098$ & 14.1 & 3.27 & 14.8 \\
\hline
\end{tabular}

These numbers are shown in Figures 1 and 2. Based on compensation, employment, and ASM information reported by the U.S. Department of Transportation, Bureau of Transportation Statistics, Form 41. Daniel Kasper and Darin Lee kindly provided current dollar figures by carrier and year on compensation and cost per ASM. Current dollar figures were converted to 2005\$ and weighted averages were formed based on carrier employment counts provided in Form 41 data. CV measures the weighted coefficient of variation (standard deviation divided by mean). See text for further details. 
Appendix Table 2: Construction of Airline Craft and Comparison Groups in the CPS

\begin{tabular}{|c|c|c|}
\hline \multicolumn{3}{|c|}{ Air Transportation Groups } \\
\hline \multicolumn{3}{|c|}{ Workers employed in air transport industry (code 421 for 1995-2002; code 6070 for 2003-2006) } \\
\hline & CPS Occ code & Occupation name \\
\hline \multicolumn{3}{|l|}{ Pilots } \\
\hline 1995-2002 & 226 & Airplane pilots and navigators \\
\hline 2003-2006 & 9030 & Aircraft pilots and flight engineers \\
\hline \multicolumn{3}{|c|}{ Flight attendants } \\
\hline 1995-2002 & 463 & Public transportation attendants \\
\hline 2003-2006 & 4550 & Transportation attendants \\
\hline \multicolumn{3}{|l|}{ Mechanics } \\
\hline \multirow[t]{3}{*}{ 1995-2002 } & 508 & Aircraft engine mechanics \\
\hline & 515 & Aircraft mechanics, except engine \\
\hline & 503 & Supervisors, mechanics and repairers \\
\hline \multirow[t]{2}{*}{ 2003-2006 } & 7140 & Aircraft mechanics and service technicians \\
\hline & 7000 & First-line supervisors/managers of mechanics, installers, and repairers \\
\hline \multicolumn{3}{|c|}{ Fleet service (ramp) workers } \\
\hline \multirow[t]{2}{*}{ 1995-2002 } & 883 & Freight, stock, and material handlers, n.e.c. \\
\hline & 887 & Vehicle washers and equipment cleaners \\
\hline \multirow[t]{2}{*}{ 2003-2006 } & 9620 & Laborers and freight, stock, and material movers, hand \\
\hline & 9610 & Cleaners of vehicles and equipment \\
\hline \multicolumn{3}{|c|}{ Agents and stores } \\
\hline \multirow[t]{3}{*}{$1995-2002$} & 318 & Transportation ticket and reservation agents \\
\hline & 364 & Traffic, shipping, and receiving clerks \\
\hline & 365 & Stock and inventory clerks \\
\hline \multirow[t]{4}{*}{ 2003-2006 } & 5410 & Reservation and transportation ticket agents and travel clerks \\
\hline & 5610 & Shipping, receiving, and traffic clerks \\
\hline & 5620 & Stock clerks and order fillers \\
\hline & 5240 & Customer service representatives \\
\hline \multicolumn{2}{|c|}{ Other air transport workers: } & All full-time air transport workers not in one of the above crafts \\
\hline \multicolumn{3}{|c|}{ Comparison Groups } \\
\hline \multicolumn{3}{|c|}{ Comparison group workers are not employed in the air transportation industry } \\
\hline \multicolumn{3}{|c|}{ Occupation codes (occupation codes and names posted at www.unionstats.com) } \\
\hline \multicolumn{3}{|c|}{ Pilot comparison group } \\
\hline 1995-2002 & \multicolumn{2}{|c|}{ 43-79; 173; 213-233; 235} \\
\hline 2003-2006 & \multicolumn{2}{|l|}{$500-1960$} \\
\hline \multicolumn{3}{|c|}{ Flight attendant comparison group } \\
\hline 1995-2002 & \multirow{2}{*}{\multicolumn{2}{|c|}{$\begin{array}{l}243-285 ; 303-389 ; 433-447 ; 456-459 \\
3600-3650 \cdot 4000-4160 \cdot 4300-4650 \cdot 4700-4960 \cdot 5000-5930\end{array}$}} \\
\hline 2003-2006 & & $3600-3650 ; 4000-4160 ; 4300-4650 ; 4700-4960 ; 5000-5930$ \\
\hline \multicolumn{3}{|c|}{ Mechanic comparison group } \\
\hline 1995-2002 & $505-549$ & \\
\hline 2003-2006 & $7000-7620$ & \\
\hline Fleet service $\mathrm{c}$ & arison group & \\
\hline 1995-2002 & $883 ; 889 ; 885-8$ & \\
\hline 2003-2006 & $9620 ; 9360 ; 961$ & ; 9640 \\
\hline Agents and sto & omparison group & \\
\hline 1995-2002 & $318 ; 323 ; 364 ; 3$ & $55 ; 327$ \\
\hline 2003-2006 & $5410 ; 5420 ; 561$ & ; 5620; 5350 \\
\hline Other worker $\mathrm{c}$ & arison group: & All full-time workers not in air transport (plus other sample criteria) \\
\hline
\end{tabular}

See text for additional details and discussion on the CPS sample. 


\section{Appendix Table 3:}

CPS Log Wage Differentials by Union and Nonunion Airline Worker Groups, 2003-2006

\begin{tabular}{|c|c|c|c|c|}
\hline Group & $\begin{array}{l}\text { Skill Index } \\
\text { Included }\end{array}$ & All & Union & Nonunion \\
\hline \multicolumn{5}{|c|}{ All Industry } \\
\hline & No & 0.132 & 0.240 & 0.042 \\
\hline & Yes & 0.117 & 0.224 & 0.027 \\
\hline \multicolumn{5}{|c|}{ Industry Crafts } \\
\hline & No & 0.220 & 0.284 & 0.131 \\
\hline & Yes & 0.194 & 0.261 & 0.102 \\
\hline \multicolumn{5}{|l|}{ Pilots } \\
\hline & No & 0.318 & 0.422 & 0.131 \\
\hline & Yes & 0.285 & 0.391 & 0.096 \\
\hline \multicolumn{5}{|c|}{ Flight Attendants } \\
\hline & No & 0.156 & 0.209 & 0.009 \\
\hline & Yes & 0.148 & 0.207 & -0.013 \\
\hline \multicolumn{5}{|c|}{ Mechanics } \\
\hline & No & 0.229 & 0.321 & 0.092 \\
\hline & Yes & 0.180 & 0.271 & 0.042 \\
\hline \multicolumn{5}{|c|}{ Fleet Service } \\
\hline & No & 0.200 & 0.126 & 0.258 \\
\hline & Yes & 0.197 & 0.126 & 0.254 \\
\hline \multicolumn{5}{|l|}{ Agents } \\
\hline & No & 0.197 & 0.229 & 0.167 \\
\hline & Yes & 0.173 & 0.206 & 0.142 \\
\hline \multicolumn{5}{|l|}{ Other } \\
\hline & No & -0.007 & 0.085 & -0.043 \\
\hline & Yes & -0.006 & 0.093 & -0.045 \\
\hline
\end{tabular}

Identical to Table 2, except that the sample period is restricted to the years 2003-2006 following a new set of occupation and industry codes. Sample sizes for specific airline crafts are very small. See note to Table 2 and discussion in the text. 